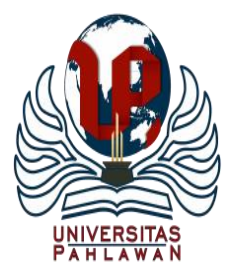

Edukatif : Jurnal Ilmu Pendidikan Volume 3 Nomor 1 Tahun 2021 Halm 27 - 34 EDUKATIF: JURNAL ILMU PENDIDIKAN

Research \& Learning in Education

https://edukatif.org/index.php/edukatif/index

\title{
Analisis Belajar Keterampilan Motorik
}

\section{Edil Rohisfi ${ }^{1 凶}$, Neviyarni $^{2}$}

Universitas Negeri Padang, Indonesia ${ }^{1,2}$

E-mail : $\underline{\text { erohisfi@gmail.com }}^{1} \underline{\text { neviyarni.suhaili911@gmail.com }}^{2}$

\begin{abstract}
Abstrak
Artikel ini membahas tentang analisis belajar keterampilan motorik menggunakan rujukan dari kajian literatur yang relevan, dalam konsepnya belajar keterampilan motorik merupakan belajar dengan tumbuh kembang kemampuan gerak tubuh seorang siswa yang meliputi perkembangan motorik kasar dan motorik halus. Ada empat karakteristik belajar keterampilan motorik, yaitu: (1) respon berurut, (2) koordinasi perceptual motorik (perceptual motor coordination), (3) pengaturan respon (respon organization), (4) umpan balik (feedback). Belajar keterampilan motorik ini dapat dibedakan dalam tiga fase atau tahap yaitu (1) fase awal atau kognitif, (2) fase fixation atau asosiatif, dan (3) fase akhir atau autonomous.
\end{abstract}

Kata kunci: belajar keterampilan motorik

\begin{abstract}
This article discusses the analysis of learning motor skills using references from relevant literature studies, in the concept that learning motor skills is learning by the development of a student's bodily ability which includes gross motoric development and fine motor skills. There are four characteristics of learning motor skills, namely: (1) sequential response, (2) perceptual motor coordination, (3) response regulation, (4) feedback. Learning motor skills can be divided into three phases or stages, namely (1) the initial or cognitive phase, (2) the fixation or associative phase, and (3) the final or autonomous phase.
\end{abstract}

Keywords: motor skills learning

Copyright (c) 2021 Edil Rohisfi, Neviyarni

$\triangle$ Corresponding author

Email : erohisfi@gmail.com

DOI: https://doi.org/10.31004/edukatif.v3i1.196
ISSN 2656-8063 (Media Cetak)

ISSN 2656-8071 (Media Online) 


\section{PENDAHULUAN}

Dalam kehidupan sehari-hari gerak merupakan aktivitas yang selalu melekat dalam kehidupan manusia, baik gerak sebagai tujuan maupun gerak sebagai alat untuk mencapai tujuan atau untuk memecahkan masalah. Secara sederhana gerak sebagai tujuan apabila gerak yang dilaksanakan merupakan objek yang ingin dicapai atau yang dinilai. Sedangkan gerak sebagai alat untuk mencapai tujuan adalah, apabila gerakan-gerakan yang dilakukan bukanlah objek yang dinilai, melainkan sebagai alat untuk mencapai tujuan dalam proses belajar.

Belajar adalah terjadinya suatu perubahan perilaku dari organisasi manusia (Annarino, 1980). Belajar juga digambarkan sebagai akumulasi pengetahuan, penyempurnaan dalam suatu kegiatan, pemecahan suatu masalah, dan penyesuaian dengan situasi yang berubah (Oxendine, 1984). Perubahan yang terjadi sebagai hasil belajar menurut (Gagne, 1989) dapat dikategorikan menjadi lima kelompok yaitu, (1) keterampilan intelektual, (2) informasi verbal, (3) strategi kognitif, (4) sikap, dan (5) keterampilan motorik. Perubahan yang terjadi pada sikap dan keterampilan motorik meliputi domain afektif dan psikomotor merupakan bentuk dalam gerakan yang menunjukkan aksi atau reaksi yang dilakukan seseorang dalam mencapai tujuan (Bloom, 1985).

Perubahan perilaku yang terjadi dalam belajar motorik ternyata dapat diamati bahkan dapat diukur dari sikap dan penampilannya dalam suatu gerakan atau penampilan tertentu (Magill, 1980). Belajar keterampilan motorik adalah belajar yang diwujudkan melalui respon-respon muskuler yang umum diekspresikan dalam bentuk gerakan tubuh atau bagian tubuh (Drowatzky, 1981). Belajar keterampilan motorik ini mengutamakan gerakan-gerakan otot, urat-urat dan persendian dalam tubuh, namum diperlukan peralatan melalui alat-alat indera dan pengolahan secara kognitif yang melibatkan pengetahuan dan pemahaman.

Keterampilan belajar motorik dapat dibagi dalam dua bagian yaitu motorik kasar dan motorik halus. Perkembangan motorik kasar yaitu perkembangan kemampuan menggerakkan sebagian dari tubuh dan kemampuan dalam tubuh secara keseluruhan (lokomotorik) yang terjadi pada waktu berjalan, berlari, melompat, olahraga, dll, sedangkan untuk perkembangan motorik halus berkaitan dengan perkembangan kemampuan dalam menggunakan jari-jari tangan untuk melakukan berbagai kegiatan seperti mengenggam, menulis, memotong, menggunting, dll (Jamaris, 2010). Meskipun tekanan belajar keterampilan motorik adalah penguasaan keterampilan, bukan berarti aspek lain seperti domain kognitif dan afektif diabaikan. Belajar motorik mencerminkan suatu kegiatan yang disadari dari mana aktivitas belajar diarahkan untuk mencapai suatu tujuan yang telah ditetapkan.

Pada artikel ini penulis ingin menganalisis mengenai belajar keterampilan motorik itu sendiri yang mana meliputi definisi belajar keterampilan motorik, kajian belajar keterampilan motorik, karakteristik belajar keterampilan motorik, fase-fase belajar keterampilan motorik, faktor faktor yang mempengaruhi belajar keterampilan motorik, teori-teori belajar keterampilan motorik, dan prinsip praktis dari belajar keterampilan motorik.

\section{METODE PENELITIAN}

Artikel ini membahas tentang analisis belajar keterampilan motorik, jenis metode penelitian ini adalah analisis kajian pustaka (literatur research) artikel ini akan memaparkan analisis jurnal ilmiah yang relevan dengan pembahasan yang sudah dipilih, materi pokok dalam analisis kajian literatur ini adalah tentang definisi, kajian, karakteristik, fase-fase, faktor-faktor yang mempengaruhi belajar keterampilan motorik, teori belajar motorik, dan beberapa prinsip praktis. tahap-tahap digunakan dalam metode penelitian analisis kajian 
literatur ini ini adalah (1) menentukan judul artikel artikel, (2) mengumpulkan data awal, (3) tantangan dari topik, (4) mengumpulkan data pendukung, (5) menghasilkan kesimpulan.

\section{HASIL DAN PEMBAHASAN PENELITIAN}

\section{A. Definisi Belajar Keterampilan Motorik}

Belajar keterampilan motorik merupakan sebuah proses dimana seseorang mengembangkan seperangkat respons kedalam suatu gerak yang terkoordinasi, terorganisasi, dan terpadu (Lutan, 1988). Belajar motorik adalah seperangkat proses yang berkaitan dengan latihan atau pengalaman yang mengantarkan ke arah perubahan permanen dalam perilaku terampil (Schmidt, 1988). Definisi belajar motorik sebagai peningkatan dalam suatu keahlian keterampilan motorik yang disebabkan oleh kondisikondisi latihan atau diperoleh dari pengalaman, dan bukan karena proses kematangan atau motivasi temporer dan fluktuasi fisiologis. Belajar keterampilan motorik ini merupakan suatu keterampilan dalam melakukan/ melaksanakan yang menunjukkan suatu susunan ketrampilan yang tinggi dalam arti perbuatan yang dimiliki siswa secara spesifik, lancar dan efisien (Ellis, 1978).

Contoh yang mudah untuk hal ini adalah mengemudi mobil, pada saat kita harus mengkordinasikan antara yang dilihat dengan apa yang dilakukan.. Adanya ketrampilan motorik ini menuntut kemampuan untuk merangkaikan sejumlah gerak gerik jasmani, sampai menjadi suatu keseluruhan yang dilakukan dengan gencar dan luwes, tanpa perlu memikirkan lagi secara mendetail apa yang dilakukan dan mengapa dilakukan.

Belajar motorik juga sebagai peningkatan dalam suatu keahlian keterampilan motorik yang disebabkan oleh kondisi-kondisi latihan atau diperoleh dari pengalaman, dan bukan karena proses kematangan atau motivasi temporer dan fluktuasi fisiologis (Rahantoknam, 1988). Belajar keterampilan motorik ini mengutamakan gerakan-gerakan otot, urat-urat dan persendian dalam tubuh, namum diperlukan peralatan melalui alat-alat indera dan pengolahan secara kognitif yang melibatkan pengetahuan dan pemahaman. Karena kompleksitas ini, belajar keterampilan motorik digunakan untuk menjelaskan fakta bahwa belajar jenis ini memerlukan koordinasi stimulus yang selaras dengan respon motorik, sering disebut juga dengan belajar persepsi motorik dan belajar keterampilan motorik mengacu pada akuisisi urutan yang tepat dari tanggapan motorik (Djamarah, 2002).

\section{B. Kajian Belajar Keterampilan Motorik}

Studi tentang belajar keterampilan motorik, membedakan keterampilan dalam dua jenis, yaitu:

1. Keterampilan motorik continuous response, yaitu keterampilan motorik yang menghendaki gerak secara terus menerus.

2. Keterampilan motorik discrete response, yaitu keterampilan motorik dilakukan interval antara setiap respon (Winarno, 1994)

Contoh dari kedua jenis keterampilan ini dapat dilihat pada atlit yang bermain bolakaki. Berlari selama bermain di lapangan adalah keterampilan motorik dengan jenis continuous response, sedangkan menendang bola adalah keterampilan motorik dengan jenis discrete response. Perbedaan mendasar antara keduanya adalah antara sesuatu yang relatif (continuous response) dan sesuatu yang arbitrary atau berubah-ubah (discrete response).

Perkembangan belajar keterampilan motorik merupakan faktor yang sangat penting bagi perkembangan individu, tercatat ada beberapa alasan tentang fungsi perkembangan motorik bagi konstelasi perkembangan individu (Yusuf, 2014), yaitu: 
1. Melalui belajar motorik anak dapat menghibur dirinya dan memperoleh perasaan senang.

2. Melalui belajar motorik, anak dapat menyesuaikan dirinya dengan lingkungan sekolah (scool adjustment).

3. Melalui perkembangan motorik yang normal akan memungkinkan anak dapat bermain dengan temannya, apabila perkembangan motorik nya tidak normal akan menghambat anak untuk dapat bergaul dengan temannya dan dia akan merasa terkucil dan menjadi anak yang "fringer" (terpinggirkan).

\section{Karakteristik Belajar Keterampilan Motorik}

Ada empat unsur pokok dari tampilan belajar keterampilan motorik, yaitu: (1) respon berurut, (2) koordinasi perceptual motorik, (3) pengaturan respon, dan (4) umpan balik. (Ellis, 1978).

\section{Respon berurut (Response sequences)}

Keterampilan motorik melibatkan suatu respon secara berurut dan cenderung membentuk suatu rantai, sehingga suatu respon akan membawa respon berikutnya. Umpamanya mengenakan tali sepatu. Sebagai urutan, respon menjadi terorganisasi, tidak hanya sekedar suatu urutan respon saja tetapi menjadi urutan yang memiliki pola terstruktu, misalnya dalam berenang, berlari, dan lain sebagainya.

\section{Koordinasi perceptual motorik (Perceptual motor coordination)}

Dalam keterampilan yang memerlukan koordinasi pesreptual motorik, semua gerakan dilakukan dengan mengkoordinasikan stimulus yang datang. Umpamanya dalam permainan bola voli, bila bola melambung dekat net maka respon pemain adalah melakukan pukulan smash. Keterampilan motorik biasanya melibatkan koordinasi input persepsi dengan tanggapan motor. Dalam hal ini semua gerakan dilakukan dengan mengkoordinasikan dengan stimulus yang datang.

\section{Pengaturan respon (Respon organization)}

Pada tampilan ini keterampilan merupakan tampilan dengan mengatur dan menggorganisasikan respon dalam sebuah pola seperti contohnya saat seseorang berenang. Setiap gerakan menerima penekanan tertentu gerakan tangan. Pernafasan, gerakan kaki merupakan sub-gerak yang merupakan rantai respon yang diatur sedemikian rupa sehingga menjadi proses berenang. Pengukuran dan pola keterampilan motorik ini dari faktor temporal (sementara) dan special (gerak).

\section{Umpan Balik (feedback)}

Keterampilan motorik memerlukan umpan balik dan tergantung pada umpan balik intrinsik, umpan balik intrinsik mengacu pada fakta bahwa respons menghasilkan rangsangan yang memiliki konsekuensi untuk tanggapan berikutnya. Dapat disimpulkan bahwa umpan balik intrinsik adalah fitur dasar belajar keterampilan motorik.

Selain itu Belajar motorik mempunyai enam karakteristik seperti yang dijelaskan (Schmidt, 1988) yaitu : (1) belajar motorik merupakan serangkaian proses, (2) belajar motorik menghasilkan kemampuan untuk merespon, (3) belajar motorik tidak dapat diamati secara langsung, (4) belajar motorik relatif permanen, (5) belajar motorik adalah karena hasil latihan, dan (6) belajar motorik dapat menimbulkan efek negatif. 


\section{Fase-Fase Belajar Keterampilan Motorik}

Meskipun belajar keterampialn motorik merupakan proses yang berkesinambungan, namun ahli psikologi membedakan belajar keterampilan motorik ini dalam tiga fase atau tahap yaitu :

1. Tahap Kognitif (Cognitive Phase). Pada tahap ini seseorang berusaha memahami apa yang diharapkan dari dirinya. Ia berusaha memahami, memverbalisasikan dan mengintelektualisasikan keterampilan tersebut dalam arti mengkonsepkan komponen-komponen tugas-tugas tersebut.

2. Tahap Asosiatif (Assosiative Phase). Pada tahap asosiasi respon yang dipelajari menjadi terintegrasi sebagai suatu rantai yang sangat efesien. Tahap ini sangat mirip dengan tahap asosiatif pada belajar verbal, karena intinya sama-sama asosiatif.contohnya adalah melakukan pekerjaan mengetik dimana orang yang mengetik harus melihat kepada keyboard.

3. Tahap Autonomous (Autonomous Phase) yaitu Pada tahap ini tampilan keterampilan motorik lebih menjadi efesien sehingga dapat dilakukan secara otomatis. Kecepatan keterampilan motorik semakin meningkat sehingga secara terus menerus memperkuat pola respon baru dan hal ini bukan hanya karena pengulangan respon yang sama. Contohnya seorang tukang ketik tidak terpengaruh oleh suara radio atau suara lainnya, bahkan ia mampu mengetik sambil berbicara dengan orang (Ellis, 1978).

\section{E. Faktor-faktor yang Mempengaruhi Belajar Keterampilan Motorik}

Adapun tiga faktor utama yang harus dipertimbangkan dalam proses belajar motorik seperti yang dijelaskan oleh (Singer, 1980) adalah :

1. Faktor proses belajar, artinya bagaimana siswa mengolah informasi sehingga terjadi otomatisasi dalam melakukan gerakan.

2. Faktor-faktor personal yang meliputi ketajaman berpikir, persepsi, intelegensi, ukuran fisik, pengalaman, emosi, kapabilitas, motivasi, sikap, jenis kelamin dan usia.

3. Faktor-faktor situasi meliputi situasi alami, dan sosial.

Kemudian Faktor yang penting yang dapat mempengaruhi keterampilan motorik yaitu (Ellis, 1978:232) :

1. Umpan balik (Feedback).

Adapun faktor yang mempengaruhi keterampilan motorik adalah umpan balik (feedback) yang terdiri dari dua jenis (a) umpan balik intrinsik yang merupakan informasi yang diterima untuk melakukan tampilan keterampilan motorik pada suatu latihan tertentu. Diperoleh secara langsung dari pengalaman dan tindakan kita. (b) umpan balik ektstrinsik yang merupakan suatu hasil pengetahuan yang menekankan ciri informal dari umpan balik.

\section{a. Pentingnya umpan balik}

Umpan balik diperlukan untuk mempengaruhi tampilan keterampilan motorik jika tidak ada umpan balik maka orang yang belajar merasa tidak ada keberhasilan bahwa ia telah menguasai suatu keterampilan motorik. Umpan balik berguna pula untuk mempengaruhi sipelajar bahwa ia telah mengalami perkembangan dalam belajarnya. Selain itu khususnya dengan umpan balik kuantitatif. Kita bisa mengatakan bahwa seorang pelajar telah memiliki keterampilan motorik yang lebih bagus ketimbang yang lainnya. 


\section{b. Penghilangan umpan balik dan Reinforcement Subjektif}

Penghilangan atau pengambilan kembali umpan balik berpengaruh terhadap tampilan keterampilan motorik, tetapi tidak berpengaruh seperti penghilangan reinforcement pada belajar instrumental. Penghilangan umpan balik ini dapat mengakibatkan penurunan tampilan secara bertahap, namun penghilangannya itu tidak sampai pada tingkat tampilan yang sedang berlangsung.

\section{c. Penundaan umpan balik}

Merupakan umpan balik yang diberikan dengan penundaan waktu antara respon subjek (si pelajar) dan umpan balik informatif. Penundaan ini ternyata tidak mempengaruhi perolehan beberapa bentuk keterampilan motorik. Namun menyebabkan penurunan serius dalam pelaksanaan latihan seperti pelacakan yang terus menerus, karena keterampilan motorik bersifat kontiniu. Umpan baliknya sangat baik dtunda seminimal mungkin.

\section{Distribusi Latihan (Distribution of Practice)}

Distribusi latihan membantu perolehan keterampilan motorik. Respon yang didistribusikan merupakan sisa interval selama proses perolehan keterampilan motorik yang berkelanjutan atau terus menerus.

\section{Stres dan Kelelahan (Stress and Fatigue)}

Stres dapat didefinisikan dengan dua cara, yaitu (1) merupakan keadaan dimana organisme (manusia) dalam keadaan termotivasi atau emosional, yang disebut juga dengan tekanan emosi, (2) sebagai permintaan tugas/pekerjaan pada seseorang, bila anda diharuskan mengikuti beberapa peristiwa sementara anda harus menyelesaikan suatu tugas/pekerjaan lainnya, maka anda akan mengalami stress yang lebih berat. Kedua definisi ini disebut dengan information overload.

\section{F. Teori-Teori Belajar Keterampilan Motorik}

Teori belajar pada keterampilan motorik dilihat sebagai proses yang dasarnya analog, atau identik dengan belajar instrumental. Tradisi ini berasal dari Thorndike, yang memandang bahwa karakteristik pembelajaran motorik sama dengan pembelajaran instrumental, tergantung pada hukum pengaruh klasik. Belajar motorik dapat dianggap sebagai sebuah proses pemecahan masalah dan mengandung unsur S-R dan konsep-konsep pembelajaran kognitif. Fitur penting dari teori ini adalah teori closed-loop. Ide dasar dari setiap sistem closed-loop adalah respon terhadap suatu sistem memberikan umpan balik pada sistem, sehingga sistem tersebut menjadi self-regulation (Ellis, 1978).

Teori belajar motorik yang disebut dengan teori jalur tertutup yang dikembangkan oleh Adam. Teori ini menyatakan bahwa proses belajar motorik berlangsung pada jalur tertutup, maksudnya umpan balik dari anggota badan yang terus menerus selama latihan merupakan sumber koreksi utama untuk kebenaran suatu gerakan (Schmidt, 1988). Dengan kata lain dapat dijelaskan, apabila seseorang melakukan sesuatu gerakan maka akan menghasilkan umpan balik intrinsik yang berguna untuk mengarahkan gerak anggota badan dan penggunaan waktu (timing) yang tepat. Kemudian ada teori skema dari (Schmidt, 1988) yang mana proses belajar motorik berlangsung pada jalur terbuka, teori skema memiliki dua kondisi memori yaitu : (a) memori ingatan, bertanggung jawab untuk memproduksi gerakan, dan (b) memori pengenalan, yang bertanggung jawab untuk mengevaluasi respons. 


\section{G. Beberapa Prinsip Praktis}

Prinsip praktis yang dapat ditarik dari bahasan belajar keterampilan motorik ini adalah (Ellis, 1978):

1. Understand the task (Pemahaman tugas), tugasnya adalah memverbalisasikan keterampilan, mencoba mengidentifikasikan komponen bagian-bagiannya.

2. Practice on specific components (melakukan latihan pada komponen tertentu), dimana saat kompleksitas tugas-tugas meningkat, maka kita memfokuskan latihan pada komponen tugas tertentu yang khusus.

3. Obtain feedback (memperoleh umpan balik), Umpan balik berguna untuk mengevaluasi tampilan keterampilan motorik dan membandingkannya dengan tampilan standar.

4. Practice under varied conditions (melakukan latihan di bawah kondisi yang bervariasi), stimulus yang bervariasi merupakan faktor penting dalam memori, dan juga praktek di dalam kondisi yang bervariasi memudahkan dalam pencapaian motorik. Untuk itukonteks variasi dalam latihan penyesuaian pencapaian ini dapat merubah ke lingkungan potensial.

5. Sustain Practice (mempertahankan latihan), karena kelancaran keterampilan motorik memerlukan latihan terus menerus.

\section{KESIMPULAN}

Belajar keterampilan motorik adalah belajar melalui respon-respon muskuler yang umum diekspresikan dalam bentuk gerakan tubuh atau bagian tubuh. Belajar keterampilan motorik ini merupakan suatu keterampilan dalam melakukan/ melaksanakan yang menunjukkan suatu susunan ketrampilan yang tinggi dalam arti perbuatan yang dimiliki siswa secara spesifik, lancar dan efisien. Studi tentang belajar keterampilan motorik, membedakan keterampilan dalam dua jenis, yaitu keterampilan motorik continuous response, dan keterampilan motorik discrete response. Ada empat unsur karakteristik yang ada pada belajar keterampilan motorik (1) respon berurut, (2) koordinasi perceptual motorik, (3) pengaturan respon, dan (4) umpan balik, sedangkan untuk faktor-faktor yang mempengaruhi belajar keterampilan motorik ini yaitu umpan balik, distribusi latihan,serta stres dan kelelahan.

Belajar keterampialn motorik ini merupakan proses yang berkesinambungan yang dibedakan belajar motorik ini dalam tiga fase atau tahap. (1) Fase awal atau kognitif, (2) Fase fixation atau asosiatif, dan (3) Fase akhir atau autonomous. Kemudian dalam teori belajar motorik ini. Teori pembelajaran motorik dipandang sebagai proses yang pada dasarnya analog, atau identik dengan belajar instrumental. Untuk prinsip praktis yang diambil dari belajar keterampilan motorik ini yaitu understand the task (pemahaman tugas), practice on specific components (melakukan latihan pada komponen tertentu), obtain feedback (memperoleh umpan balik), practice under varied conditions (melakukan latihan di bawah kondisi yang bervariasi), dan sustain practice (mempertahankan latihan).

\section{DAFTAR PUSTAKA}

Annarino, A, A. \& Cowel. (1980). Curriculum Theory and Design in Physical Education. St. Louis: CV Mosby Company.

Bloom, B. (1985). Taxonomy of Educational Objectives. Newyork: Longman Hall Inc.

Djamarah, S.B. (2002). Psikologi Belajar. Jakarta: Rineka Cipta.

Drowatzky, J, N. (1981). Motor Learning Principle and Practice. Minneapolis: Burger Publishing Company.

Ellis, H, C. (1978). Foundamentals Of Human Learning, Memory and Cognition (2 ${ }^{\text {nd }}$ Edition). Iowa: Wm. C. Brown Company Publisher. 
Gagne, R, M. (1989). Kondisi Belajar dan Teori Pembelajaran. Terjemahan Munandir dan Kartawinata, H. Jakarta: Depdikbud Ditjen Dikti.

Jamaris, M. (2010). Orientasi Baru dalam Psikologi Pendidikan. Jakarta: Yayasan Penamas Murni.

Lutan, R. (1988). Belajar Keterampilan Motorik Pengantar Teori dan Metode. Jakarta: P2LPTK Dirjen Dikti Depdikbud.

Magill, R, A. (1980). Motor Learning, Concept and Application. Dubuqua, Luwa: WM.C Brown Publisher.

Oxendine, J, B. (1984). Psychology of Motor Learning. New Jersey: Prentice Hall Inc.

Rahantoknam, B, E. (1986). Belajar Motorik. Jakarta: Proyek Pengembangan Perguruan Tinggi IKIP Jakarta.

Schmidt, R, A. (1988). Motor Control and Learning. Second Edition. lllinois: Human Kineticks Publisher Inc.

Singer, R, N. (1980). Motor Learning and Human Performance. Newyork: Macmillan Publishing Company.

Yusuf, S, L, N. (2014). Psikologi Perkembangan Anak \& Remaja. Bandung: PT Remaja Rosdakarya.

Winarno. (1994). Belajar Motorik. Malang: Depdikbud IKIP Malang. 